\title{
Review Essay/Samlingsrecension
}

Ulla Rhedin och Gunna Grähs (red.). Vår Pippi - Vår Vang: Tecknarna hyllar Ingrid Vang Nyman och det moderna genombrottet inom svensk barnboksbild. Lidingö: Salikon, 2016 (225 s.)

\section{Lena Törnqvist. Ingrid Vang Nyman: En biografi. Lidingö: Salikon, 2016. Astrid Lindgren-sällskapets skrifter, nr 8 (192 s.)}

År 2016 skulle Ingrid Vang Nyman ha fyllt hundra år, vilket föranlett bokförlaget Salikon att ge ut två böcker om konstnären och illustratören. Ambitionen i både Lena Törnqvists biografi och Ulla Rhedins och Gunna Grähs antologi är att vidga bilden och berätta mer än att Ingrid Vang Nyman skapade den visuella bilden av Pippi, även om Pippigestalten naturligt nog upptar en stor plats i verken.

Förutsättningarna för de båda böckerna är gynnsamma. Törnqvist har en stor kompetens i att arbeta med brev och andra dokument och genom dem sammanställa en berättelse. Hon fortsätter här att vara den ovärderliga brevfinnare hon visat sig vara, som i arbetet med Lindgrensamlingen på Kungliga biblioteket (KB), även då breven i detta fall inte i så hög grad finns där utan i privata samlingar och på andra bibliotek. När det gäller antologin Vår Pippi - Vår Vang finns det en fördel i att boken ges ut på ett förlag närstående Saltkråkan som är det bolag som äger rättigheterna till bilderna. Den är fylld till bredden med intressanta och välkända illustrationer, men också en hel del obekanta. Bilderna är antologins starka sida och utgör den tydligaste presentationen av Ingrid Vang Nymans verk. Rhedin och de illustratörer, tecknare och konstnärer som skriver verkar ha haft fri tillgång till allt de velat ha, och det har utnyttjats till att stärka de texter de själva skrivit. Kopplingen är inte alltid glasklar mellan text och bild, men det är heller inte nödvändigt då överflöd är det som verkar ha varit ledstjärnan i framställningen. Det är möjligt att se det som att den privata Ingrid Vang Nyman presenteras i Törnqvists biografi medan resultatet av det yrkesverksamma livet framställs i antologin. Jag vet inte om det var meningen - märkligt nog hänvisas inte på något ställe i verken till den andra skriften, även om båda projekten rimligen bör ha växt fram samtidigt, på samma förlag.

Lena Törnqvists bok om Ingrid Vang Nyman har ingen underrubrik, annat än "En biografi". Det är rättvisande eftersom något särskilt perspektiv inte anläggs, ej heller fokuserar texten på någon 
viss period eller del av verksamheten. Framställningen styrs av det brevmaterial och de intervjuer som har funnits till hands, och det räcker långt. Därför tas heller ingen större hänsyn till annan forskning om konstnärer från tiden, den danska illustrationstraditionen eller liknande. Ambitionen är inte att vara heltäckande eller att på ett mer fördjupat plan försöka förstå bakgrunden till de bilder Vang Nyman skapade.

Vid sidan av att teckna en allmän bild av Vang Nymans liv är den viktiga frågan varför illustratören inte blev lika berömd som sin figur Pippi, och varför hennes bilder inte kom att spridas över världen på samma sätt som Lindgrens berättelser. Denna fråga formulerar Törnqvist tydligt $\mathrm{i}$ inledningen och hon besvarar den på ett övertygande sätt.

Törnqvist redogör inledningsvis för det material hon bygger sin framställning på. En viktig startpunkt för insamlandet verkar utställningarna över Ingrid Vang Nyman i Vejen, Danmark och på Kungliga biblioteket 2003 vara. De resulterade också i fylliga kataloger, KB:s redigerades just av Törnqvist. Med en arkivaries entusiasm skriver Törnqvist om släktförhållandena kring den person hon intresserar sig för, och hur olika människor i denna skara leder henne vidare till nya samlingar av brev som inte fanns tillgängliga 2003. "I breven framträdde en mer privat bild av människan Ingrid Vang Nyman och hennes oftast mycket problemfyllda liv" (11) skriver Törnqvist, för att dels ge ett samlat omdöme om vad det nya materialet kan tillföra för kunskap, dels förklara vad det är för historia som väntar läsaren av biografin. Törnqvist gör också de nödvändiga reservationerna - "allt skriver man inte om till svärmor" (11) - och även gällande hennes egen tolkning av handstilen. Hon kallar sin tolkningsprocess för att läsa mellan raderna och att låta frågetecknen stå kvar där de behövs.

I det första kapitlet ges en bild av en allt annat än trygg barndom men också av hur konstnärsdrömmarna tar gestalt. En målarskola i Köpenhamn omnämns, liksom Kunstakademien i Köpenhamn. Törnqvist skriver att åren på akademien är avgörande för att forma Ingrid Vang Nymans liv eftersom hon där möter Arne Nyman. Men huruvida konstakademien sätter spår i hennes konstnärskap får läsaren ingen upplysning om, och det är omöjligt att veta om det beror på att sådan information saknas i breven, eller om Törnqvist inte behandlar detta. En upplysning om detta hade gärna fått ges.

Det följande kapitlet heter följdriktigt "Åren med Arne" men självklart får vi här också ta del av hur Ingrid Vang Nyman tecknar och målar. "Våren 1940 börjar också idén att tillfälligt försörja sig 
på illustrationsuppdrag att allt oftare dyka upp, framförallt i Arnes brev" (40). En barnbok verkar vara påtänkt och påbörjad men inte avslutad och utgiven. Från år 1943 finns det också genom breven spår efter försök med en barnbok.

Allt det som omnämns i de två första kapitlen är på de flesta sätt okänt. Styrkan ligger i presentationen av den bakgrund som Ingrid Vang Nyman kommer ur, samtidigt som framställningen präglas av det som Törnqvist i inledningen pekar ut som sitt problem - man måste i breven läsa mellan raderna och många pusselbitar saknas. Intressantast blir därför det kapitel som närmar sig det som redan blivit omskrivet tidigare i skildringen av relationen mellan Lindgren och Nyman. Här ges en fördjupning och förklaring med hjälp av nya källor och ett perspektiv taget från konstnärens sida gentemot det svenska förlaget och utländska motsvarigheter. I kapitlet "Stockholm" beskrivs först hur tecknarkarriären tar fart innan uppdraget med Astrid Lindgrens texter behandlas. Här finns en analys av bilderna som fungerar bäst i de konkreta exemplen, då exempelvis kompositionen i Känner du Pippi Långstrump? (1947) jämförs med relationen mellan bild och text i tidigare verk av Vang Nyman. Genom den tydliga jämförelsen blir det nya och det banbrytande då det gäller exempelvis komposition, färgval och synvinklar framträdande. Svårare är det när en mängd begrepp används utan att tydligt få sin koppling till illustrationerna eller till en specificering av vad som menas. Bilderna är vare sig gulliga eller insmickrande skriver Törnqvist, och det följs av meningen: "Hennes avsikt är inte att skildra barndomen idylliskt och romantiskt, snarare handlar det om en humoristisk realism med dragning mot naturalism" (96 f.). Av det blir man inte klokare, utan kommer mer att fundera på vad som egentligen är gulligt eller idylliskt i bilderna. De knubbiga barnen som rultar fram på Bullerbyillustrationerna kan nog lika gärna ses som "gulliga" och i relation till textens beskrivning av lekar och upptåg kan bilden också uppfattas som idyllisk. Eventuellt ges Törnqvists beskrivning i relation till Ilon Wiklands senare illustrationer av Bullerbyberättelsen, men de bilderna diskuteras inte och detta blir därför inte uppenbart. Vad som menas med realism och naturalism är än större frågor.

Kapitlets starka sida är istället beskrivningen av det som tidigare mest behandlats som Vang Nymans knepiga sida, som tog sig uttryck i att hon blev osams med de flesta uppdragsgivare och därigenom förlorade många inkomstmöjligheter. Ett brev formulerat i skarp ton från Lindgren till Vang Nyman har sedan tidigare varit känt, men här publicerar Törnqvist utdrag ur en större mängd brev mellan 
Lindgren och olika förläggare. De visar på en författare som så långt det är möjligt försöker bereda vägen för ursprungsillustrationerna, men som samtidigt minst av allt vill ha bråk eller själv drabbas av en uppfattning av att vara omöjlig att ha att göra med. Lindgren går en svår balansgång som tyvärr slutar med att Vang Nyman offras för att inte Lindgren ska dras med.

Törnqvist skriver återkommande om Vang Nymans psykiska problem men i det här avseendet ser hon besvärligheten snarare som ett uttryck för en tidig medvetenhet om tecknarens rättigheter till sina verk och sina verks värde. Detta var samtiden ovan vid, både förlag och författare. Bilder brukade följa med på köpet med texten eftersom illustratören fått betalt en gång för alla, medan författaren däremot kunde förhandla om ersättningen vid en nyutgåva eller översättning. Ingrid Vang Nyman stod på sig och förlorade därigenom. Här ges svar på den fråga som Törnqvist inledningsvis ställer och hon bevisar arkivforskningens betydelse för litteraturvetenskapen. Ett tillvägagångssätt där man bara studerat olika länders illustrationer av Lindgrens verk hade mycket väl kunnat komma fram till att det var andra länders bildtradition som satte käppar i hjulet för att även bilderna följde med ut i världen. Törnqvist visar att det var oförmågan att kompromissa och vara till lags som får Vang Nymans hjul att sluta snurra. Detta visas genom ett flertal kontroverser gällande olika verk och utlandsförlag. Därigenom visar Törnqvist både en mer omsorgsfull sida av Lindgren, som faktiskt gjorde allt hon kunde, men också att även hon egentligen ställde sig frågande inför kraven och rättighetsanspråken. Både bilden av Lindgren och Vang Nyman fördjupas således.

Några saker finns att anmärka på. En är den sparsmakade användningen av andras kunskaper om bildtraditionen från den här tiden. Elina Drukers avhandling Modernismens bilder. Den moderna bilderboken i Norden från 2008 hade kunnat sätta in Vang Nyman i ett sammanhang, likaså borde den uppföljande boken av Druker om Eva Billow från 2014 kunnat bidra med perspektiv gällande hantverksprocessen. När det gäller Kunstakademien i Köpenhamn bör det också finnas andra källor att gå till, för att tydligare kunna beskriva vad det var Vang Nyman fick lära sig och möta där. Detta leder också över till verkets andra brist - avsaknaden av hänvisningar. Där är just skolan, utbildningen och de första bilderboksförsöken något man kan tänka sig att andra vill följa upp och gå vidare med. Men nu är det högst otydligt varifrån olika uppgifter kommer. Det solkar inte framställningens trovärdighet men är ohjälpsamt gentemot de som kommer efter. Enkla hänvisningar till vilka brev som ger vilka 
upplysningar skulle göra att fler kunde fortsätta studiet av det konstnärskap som Törnqvist genom sin bok visat vara mycket intressant. Mot det kan man invända att den allmänna läsaren inte önskar dessa upplysningar, men antalet potentiella läsare som skräms bort med noter är nog marginellt. Det hela handlar om ifall man som forskare och författare ser sig som en solitär eller som en del i en gemenskap där vi tillsammans frambringar ny kunskap.

Ingrid Vang Nymans liv ändade på ett tragiskt sätt. Här går Törnqvist varsamt fram och skildrar det med en finkänslighet som är berömvärd. En spekulativ framställning hade möjligen tagit sin utgångspunkt i detta, men Törnqvist tycks mena, utan att skriva ut det, att Vang Nyman skapar och är produktiv trots sina psykiska åkommor, inte som hävdats så ofta annars, genom sin skörhet och instabilitet. Sjukdomen och självmordet romantiseras inte - det är den konstnärliga verksamheten och verken som detta resulterar i som är det viktiga.

Vår Pippi - Vår Vang. Tecknarna hyllar Ingrid Vang Nyman och det moderna genombrottet inom svensk barnboksbild har ett syfte som blir tydligt redan genom undertiteln. En värme inför konstnärskapet ses i alla bidrag som på olika sätt närmar sig bilderna och den egna upplevelsen. Jan Lööf, Eva Lindström, Pija Lindenbaum med flera ställer samman några av sina bilder med Vang Nymans och skriver i olika grad specifikt om vad som påverkat dem. Det går inte alltid att utifrån se den påverkan som omskrivs men det viktiga här är den personliga upplevelsen, inte en gemensam analys.

Andra skapar nya bilder för just den här antologin, såsom Emelie Östergren, genom en serie, och Karin Cyrén och Siri Ahmed Backström som skildrar sitt besök på Svenska barnboksinstitutet genom samma medium. För dem står färgerna i centrum, koloreringen, så också för Gunna Grähs som tar upp hur bilderna flera gånger får nya färger och till viss del förvanskas. Just mot förlagens förändringar riktas återkommande kritik, främst av Grähs. Grähs står för den största delen av verkets text och hennes huvudstycke behandlar ett liknande tema som Törnqvists bok, illustratörens rätt till sina bilder och till rimlig ersättning. Grähs talar inifrån skrået och visar på att mycket återstår att åtgärda. Detta är intressant, liksom även Grähs korta analyser av illustrationerna. Däremot borde de inte ha spridits ut över hela verket utan skulle istället ha tjänat på att hållas samman i ett avsnitt, där ett längre resonemang hade kunnat föras.

Håkan Hardenborgs kapitel "Hon gav oss bilden av Pippi" är det andra längre avsnittet $\mathrm{i}$ boken. Det är tidigare publicerat och utgör en grund även för Törnqvists framställning. Här har Hardenborg 
utvecklat texten och ger oss en biografisk grund till det som senare ska komma i antologin. De delarna är mest betydelsefulla medan den bildanalys som också utförs framstår som omotiverad. Så är det i ett flertal texter - varför står den här bilden i centrum och med vilket syfte, frågar man sig? Tanken hoppar fritt, och så kan det få vara. Men såsom i Lennart Engs text, som har en tydlig avsikt - att pröva tanken om Vang Nyman kan ses som "en huvudperson i spelet som gav oss den moderna bildgestaltningen för barn" (52) - vore det intressant att veta varför två opublicerade bilder utgör grunden för resonemanget. Kopplingar görs främst till Vincent van Gogh i Engs kapitel, inte till andra samtida bilderbokskonstnärer, och uppmaningar som "tänk grottmålningar" eller beskrivningar som "komplex enkelhet" gör det mest bara obegripligt. Nej, bäst är Vår Pippi - Vår Vang i de helt personliga avsnitten och det är berömvärt att Ulla Rhedin lyckats få ihop en sådan bredd bland de medverkande, vad gäller ålder, tekniker och berättande. Sedan kan man tycka att en av Sveriges mest erfarna bilderboksforskare kunde låta bli att motivera antologins tillkomst med att Ingrid Vang Nyman satt få avtryck i barnlitteraturforskningen. Är det någons bilder det finns artiklar om är det ju Vang Nyman. Flertalet av dem saknas i den avslutande referenslistan. De har heller inte varit nödvändiga för den här antologins framväxt, men Rhedin känner garanterat till dem.

En som saknas i antologin är Anna Clara Tidholm, som en gång uppgivet konstaterade att det bara är tanten Lindgren som får någon större uppmärksamhet när det gäller barnlitteratur. Det har hon i hög grad rätt i. Och argumentet att något inte gjorts förut är aldrig särskilt starkt för en studie eller ett verks tillkomst. Då är viljan att samla ett antal "illustratörsblickar", Rhedins term, på Vang Nymans konstnärskap ett mycket starkare och bättre argument. Det har Rhedin och Grähs verkligen lyckats med.

Martin Hellström

Universitetslektor i litteraturvetenskap

Linnéuniversitet 